\title{
Pengaruh Penggunaan Pulsa Tegangan sebagai Desulfator terhadap Pemulihan Kapasitas Baterai Berbahan Lead Acid
}

\author{
Ahmad Juang Pratama ${ }^{1}$, Hamzah Firdaus \\ ${ }^{1}$ Program Studi Teknik Industri Fakultas Sains dan Teknologi \\ Universitas Al Azhar Indonesia, Jl. Sisingamangaraja, Jakarta 12110 \\ ${ }^{1}$ Penulis untuk korespondensi/Email: juang@uai.ac.id
}

\begin{abstract}
Abstrak-Pengecasan dengan menggunakan teknik pulsa arus adalah salah satu teknik yang dapat digunakan untuk mengatasi kehilangan kapasitas aki secara prematur. Teknik ini bisa mempercepat proses pengecasan aki dan memperpanjang siklus hidup sebesar 3 sampai 4 kali dibandingkan dengan pengecasan konvensional dengan arus konstan. Lebih panjangnya siklus hidup baterai berbahan lead acid (BLA) ini dikarenakan teknik pulsa tegangan bersifat sebagai desulfator yaitu pengurai Kristal senyawa timbal sulfat $\left(\mathrm{PbSO}_{4}\right)$ yang menempel pada elektroda dan menjadi penyebab utama BLA kehilangan kapasitas secara prematur. Penelitian dilakukan untuk melihat efek pemulihan / desulfator, dimana BLA yang sudah lemah karena sudah terpakai di treatment dengan pulsa tegangan akan mengembalikan kapastias simpan BLA, menggunakan prototype yang telah dibuat. Dari eksperimen yang dilakukan terlihat peningkatan nilai Daya starter dan peningkatan durasi pembebanan pada BLA.

Abstract - Battery charging using pulse technique is a technique that can be used to overcome the premature loss of battery capacity. This technique can speed up the process of charging and extended battery life cycle 3 to 4 times compared with conventional charging using constant current. The Longer life cycle of Lead Acid Battery is because the technique has desulfator effect. Voltage pulse decomposite timbale sulfate $\left(\mathrm{PbSO}_{4}\right)$ attached to the electrode which is the main cause of the premature loss of capacity . This study will investigate the effects of the recovery of battery capacity for used weak Lead Acid Battery. Voltage pulses will be applied to the battery using a charger/desulfator prototype. The experiment results show that there is improvement of Cold Cranking Amps Level and Load time duration of the Lead Acid Battery.
\end{abstract}

Keywords - BLA(Lead Acid Battery) desulfator, pulse voltage, lead sulfate

\section{PENDAHULUAN}

$\mathrm{B}$ aterai berbahan Lead Acid (BLA) sejak ditemukan lebih dari satu setengah abad yang lalu hingga sampai saat ini digunakan secara luas dan diperkiraan milyaran dolar Amerika dialokasikan untuk berbagai aplikasi.

Penggunaan BLA ini juga berdampak bagi pencemaran lingkungan terutama diakibatkan limbah bekas baterai yang sudah lemah atau rusak. Karena itu upaya untuk memperpanjang usia pemakaian baterai ini adalah cara yang mungkin ditempuh untuk mengatasi persoalan tersebut.

Pengecasan dengan menggunakan teknik pulsa arus adalah salah satu teknik yang dapat digunakan untuk mengatasi kehilangan kapasitas aki secara prematur. Teknik ini juga bisa mempercepat proses pengecasan aki dan memperpanjang siklus hidup sebesar 3 sampai 4 kali dibandingkan dengan pengecasan konvensional dengan arus konstan [1]. Lebih panjangnya siklus hidup BLA ini dikarenakan teknik pulsa tegangan bersifat sebagai desulfator yaitu pengurai Kristal senyawa timbale sulfat ( $\mathrm{PbSO} 4)$ yang menempel pada elektroda dan menjadi penyebab utama BLA kehilangan kapasitas secara prematur.

Walaupun dalam beberapa ekperimen telah diperlihatkan peningkatan beberapa kali siklus hidup BLA menggunakan pulsa tegangan, namun tidak ada yang secara langsung mempublikasikan fungsi pemulihan BLA dengan menggunakan 
pulsa tegangan. Eksperimen-eksperimen yang dilakukan lebih sering dilakukan dengan membandingkan siklus pengisian BLA dengan menggunakan charger konvensional. Walaupun memberikan hasil yang jauh lebih baik dibanding metode konvensional, efek yang terlihat pada baterai adalah degradasi kapasitas BLA meskipun terjadi dalam jangka waktu yang jauh lebih panjang [2].

Penelitian ini dilakukan untuk melihat efek pemulihan/desulfator, dimana BLA yang sudah lemah karena sudah terpakai di treatment dengan pulsa tegangan menggunakan prototype yang telah dibuat. Hal ini lebih dekat kepada realita seharihari dimana teknik pulsa tegangan belum digunakan secara luas sebagai upaya predictive maintenance dalam berbagai aplikasi. Dalam arti pemakaian teknik pulsa tegangan lebih sering diterapkan pada BLA yang telah kehilangan kapasitas karena pemakaian, dengan demikian teknik ini lebih berfungsi sebagai teknik corrective maintenance.

\section{Tujuan Penelitian}

Tujuan penelitian ini adalah:

1. Meneliti efek pemulihan kapasitas baterai berbahan asam timbal (lead Acid) dengan menggunakan pulsa tegangan dari baterai yang memiliki kapasitas penyimpanan rendah.

2. Memverifikasi fungsi prototype penghasil pulsa tegangan yang telah dibuat sebelumya.

\section{Perumusan Masalah}

Bagaimana pengaruh pemberian pulsa tegangan terhadap pemulihan kapasitas BLA kapasitaslemah setelah melalui siklus pengisian-pembebanan dengan pembebanan c20? Hal ini dapat dilihat berdasarkan nilai daya starter/cold cranking amps dan perubahan durasi pembebanan pada BLA.

\section{Ruang Lingkup}

Penelitian dilakukan secara ekperimental dengan menggunakan spesimen baterai otomotif yang beredar di pasaran. Proses pengisian dilakukan dengan menggunakan prototype yang telah dibuat sementara kecepatan pembebanan arus mengikuti rate c20 mengikutispesifikasi yang tertera pada brosur produsen BLA.

\section{Kontribusi}

Memberikan data awal untuk inovasi teknologi yang berwawasan ramah lingkungan di Universitas Al Azhar Indonesia.
Selain itu diharapkan akan menambah jumlah publikasi jurnal ilmiah terakreditasi atau publikasi internasional di Universitas Al Azhar Indonesia.

\section{KERANGKA TEORI}

\section{Proses pada pengecasan dan pembebanan baterai}

BLA menggunakan anode berbahan timbal $(\mathrm{Pb})$ dan katode berbahan timbal dioksida $\left(\mathrm{PbO}_{2}\right)$, $\mathrm{H}_{2} \mathrm{SO}_{4}$, dan separator diantara 2 elektroda. Reaksi kimia yang terjadi pada elektroda positif dan elektroda negatif pada baterai adalah sebagai berikut [3]:

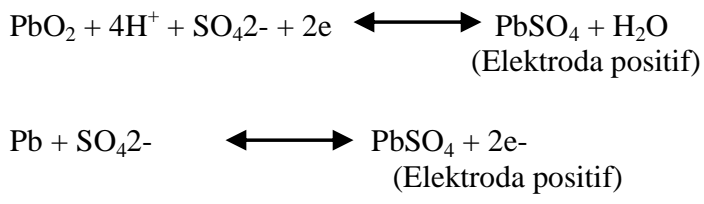

Berdasarkan reaksi diatas $\mathrm{PbSO}_{4}$ akan terbentuk pada elektroda positif dan elektroda negatif selama proses pembebanan/penggunaan baterai. Sementara pada proses pengecasan $\mathrm{PbSO}_{4}$ akan terurai dan elektroda menjadi $\mathrm{Pb}, \mathrm{PbO}_{2}$ dan $\mathrm{H}_{2} \mathrm{SO}_{4}$ [4]. Konstruksi BLA dapat dilihat pada Gambar 1.

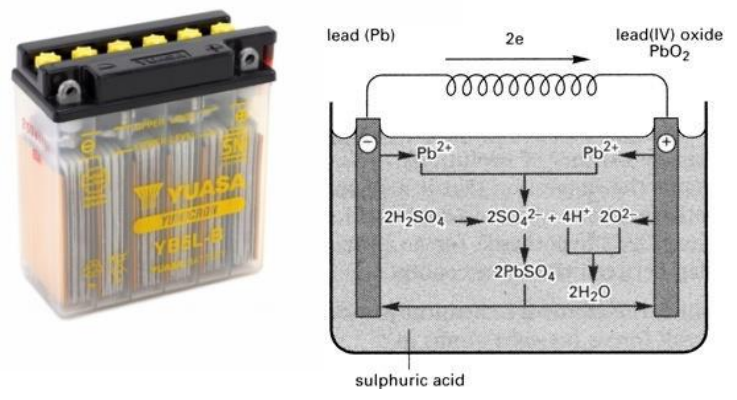

Gambar 1. Konstruksi BLA

Reaksi elektrolisis ini bersifat reversibel dan seharusnya berjalan terus menerus.Tetapi pada kenyataannya dengan berjalannya siklus pengisian dan pembebanan BLA, ada titik tertentu dimana arus berhenti mengalir walaupun telah diberikan tegangan.Hal ini diakibatkan oleh bertambahnya hambatan dalam (internal resistance). Lebih singkatnya, BLA tidak dapat lagi memiliki kapasitas penyimpanan [5].

\section{Sulfatisasi}

Hal yang menjadi faktor utama dari peningkatan internal resistance ini adalah sulfatisasi yang disebabkan oleh adanya kristalisasi dari $\mathrm{PbSO}_{4}$ selama proses pembebanan BLA. Pada proses 
pengisian $\mathrm{BLA}, \mathrm{PbSO}_{4}$ akan diurai menjadi ion $\mathrm{Pb}^{2+}$ dan $\mathrm{SO}_{4}^{2-}$, pada kenyataannya ada timbal sulfat yang tidak terurai dan membentuk kristal dan menempel pada elektroda [5]. Dengan berulangnya siklus pengisian dan pembebanan kristal ini secara bertahap menutupi dan menyumbat rongga pada elektroda yang memperkecil area kontak dengan $\mathrm{H}_{2} \mathrm{SO}_{4}$.

\section{Desulfatisasi}

Desulfatisasi dapat dilakukan dengan cara pemberian pulsa tegangan sehingga terjadi pemurnian plat timbal sulfat yang berakibat pada pulihnya sebagian kapasitas aki. Adapun bentuk dari pulsa tegangan dapat dilihat pada Gambar 2.
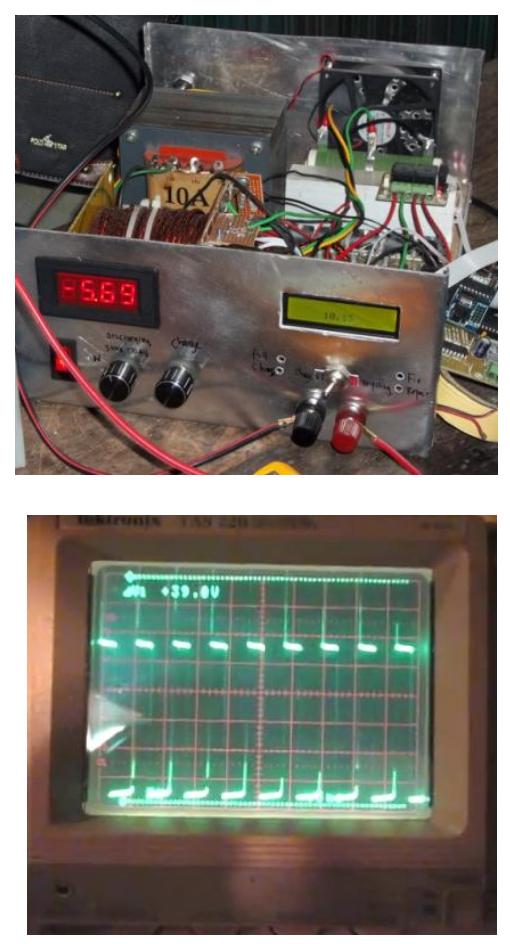

Gambar 2.Desulfator dan Pulsa Tegangan

\section{Kapasitas BLA dan Hukum Peukert}

Pengertian kapasitas baterai mengacu pada jumlah energi yang dapat disimpan baterai. Produsen BLA sering menggunakan spesifikasi yang dikenal sebagai Amp Hou runtuk memberikan indikasi kapasitas baterai yang tersimpan. Tetapi kapasitas BLA akan ditentukan oleh besarnya arus pembebanan. Artinya semakin besar pembebanan pada BLA semakin kecil pula kapasitas BLA. Fenomena ini disebut sebagai hukum Peukert.

\section{Jenis-jenis BLA}

Berdasarkan penerapannya, BLA dapat dibagi menjadi beberapa tipe [1]:
1. SLI (Start, Lighting, Ignition) yang digunakan pada otomotif.

2. Stationary untuk mendukung catu daya untuk menghasilkan dan menyimpan energi listrik yang digunakan pada sistem telekomunikasi, pusat utilitas listrik, dan sistem komputer.

3. Traksi untuk sumber tenaga peralatan transportasi seperti forklift, mobil listrik, dan perlengkapan pertambangan

4. Baterai khusus yang dimaksudkan untuk penggunaan pesawat terbang, kapal selam dan peralatan militer.

\section{Daya Starter}

Dunia industri menggunakan standar daya starter otomotif dengan ukuran Cold Cranking Apms(CCA). Standar ini menunjukkan kemampuan BLA memberikan arus pada suhu $18^{\circ} \mathrm{C}$ selama 30 detik. Sementara bisa bertahan pada voltase 1,2 volt per sel BLA atau lebih tinggi.

\section{Depth of Discharge}

Depth of Discharge (DOD) digunakan untuk menunjukkan berapa dalam pembebanan pada suatu baterai. Jika baterai $100 \%$ penuh maka DOD dari baterai tersebut adalah 0\%, jika baterai menggunakan $30 \%$ dari energinya dimana masih $70 \%$ tersimpan maka dapat dikatakan baterai ini memiliki DOD 30\%.

\section{METODE PENELITIAN}

\section{Langkah penelitian}

Alur penelitian ini dapat dilihat pada Gambar 3. Penelitian ini dimulai dengan studi literatur yang dilanjutkan dengan persiapan spesimen yang akan diuji. Persiapan spesimen ini dimaksudkan untuk mendapatkan spesimen BLA yang memiliki kapasitas penyimpanan lemah, sehingga dapat diketahui sejauh mana efek pemulihan kapasitas BLA dengan menggunakan teknik pulsa tegangan. Persiapan spesimen ini dilakukan dengan melalukan pembebanan arus dengan kecepatan c20 selama 30 siklus.

Setelah spesimen siap, dilakukan pengisian dengan teknik pulsa tegangan dan pembebanan dengan kecepatan c20 sesuai spesifikasi pabrik yang tertera pada brosur.

Untuk dilakukan pengambilan data kapasitas BLA sepanjang siklus pengisian untuk dianalisa efek pulsa tegangan terhadap pemulihan kapasitas BLA 


\section{Data dan Sumber Data}

Data:

1. Hasil pengukuran voltase,

2. Waktu dan kapasitas.

3. Daya starter BLA.

Sumber Data:

1. Intrumen pengukuran kapasitas.

2. Spesifikasi produsen BLA.

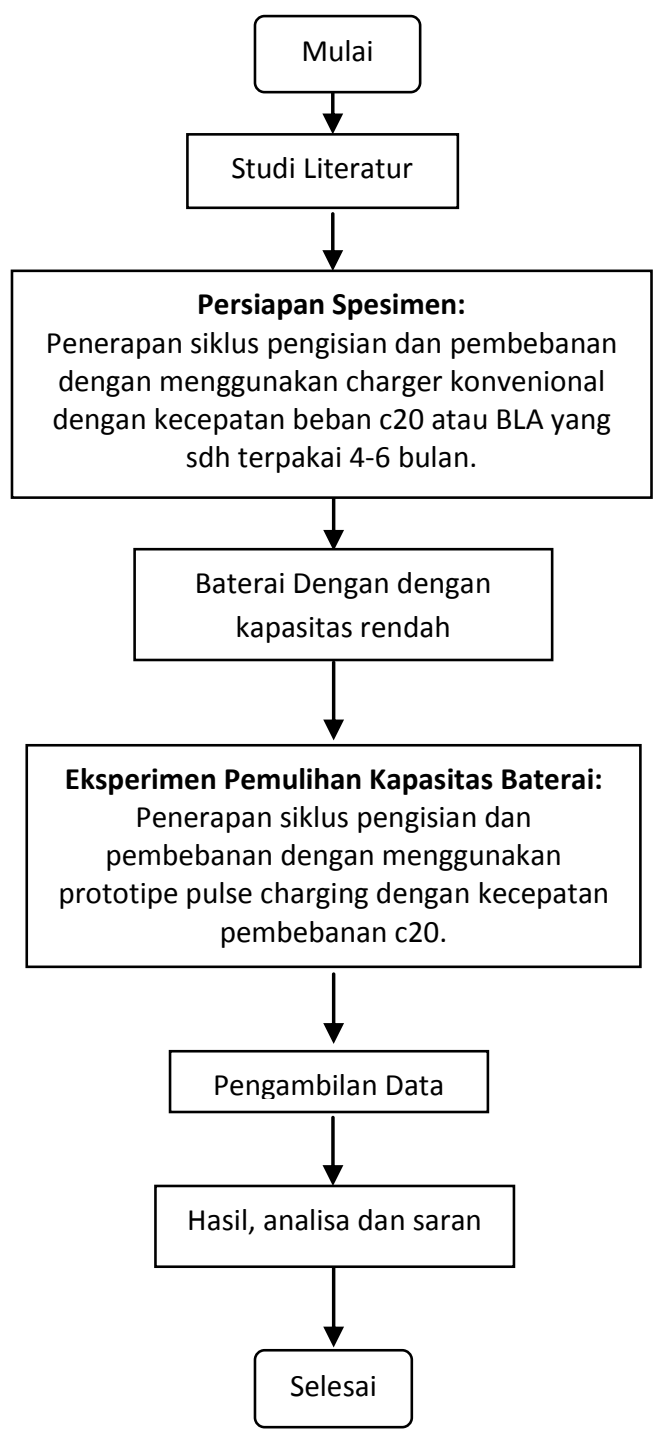

Gambar 3Tahapan Penelitian

\section{HASIL DAN PEMBAHASAN}

\section{Persiapan Spesimen}

Spesimen yang digunakan adalah BLA berjenis NS60 yang telah terpakai selama 4-6 bulan pada kendaraan, dengan kondisi Voltage 12.29 Volt, daya starter $195 \mathrm{CCA}$, sehingga tidak berada dalam kondisi awal dengan memiliki nilai daya starter yang rendah, menurut standard yang dikeluarkan oleh Yuasa, NS 60 memiliki standar daya starter sebesar 325 CCA [6]. Selain dari nilai daya starter kapasitas BLA baru juga bisa dilihat melalui nilai voltasenya, BLA yang memiliki nilai voltase $12,65 \mathrm{~V}$ dikatakan memiliki kapasitas $100 \%, 12,40 \mathrm{~V}$ dikatakan memiliki kapasitas sebesar 75\% [7].

\section{Eksperimen dan Pengambilan Data}

BLA yang telah terpakai diukur dengan Battery Analyzer DHC BT 747, untuk mengetahui kondisi awal daya starter/kapasitas BLA. Selanjutnya BLA yang telah diukur diberikan pulsa kejutan dengan frekuensi $2 \mathrm{KHz}$, sampai voltase BLA mencapai 13,5 V. Setelah itu BLA diistirahatkan selama 60 menit sampai didapatkan voltase yang stabil untuk kemudian diukur kembali dengan Battery Analyzeruntuk mengetahui nilai daya starter BLA, selanjutnya dibebankan dengan kecepatan pembebanan c20, 27 watt selama 60 menit. Siklus ini dilakukan berulangkali selama 20 Siklus sehingga perubahan nilai daya Starter CCA setiap siklus charging dan discharging dapat dapat diketahui. Sirkuit penghasil pulsa tegangan dapat dilihat pada Gambar 4. Sedangkan bentuk pulsa yang dihasilkan dapat dilihat pada gambar 5 .

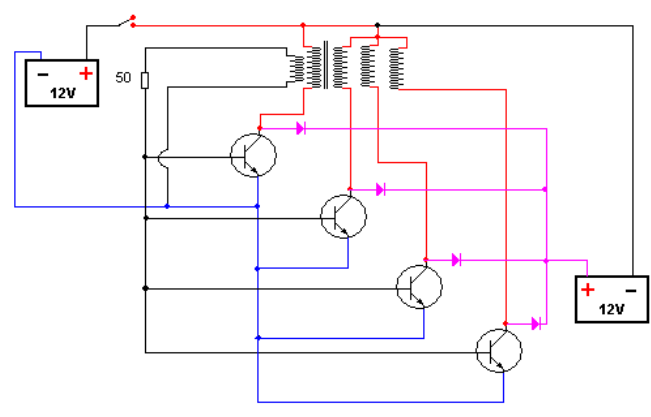

Gambar 4 Sirkuit Rangkaian Pulsa Kejutan

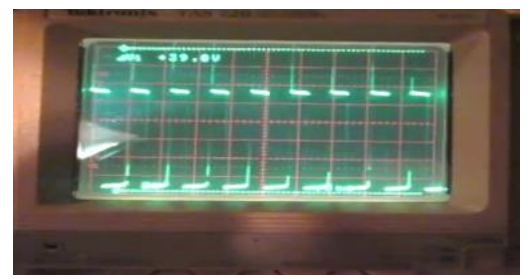

Gambar 5 Bentuk Pulsa Kejutan

\section{Pengaruh Pemberian Pulsa Tegangan Terhadap Pemulihan Kapasitas BLA}

Dari data hasil eksperimen, dapat diketahui bahwa daya starter baterai mengalami peningkatan sampai kondisi mendekati standar awal BLA, dimana penambahan nilai daya starter yang paling 
signifikan adalah pada 2 siklus pertama, sementara pada siklus selanjutnya terjadi peningkatan nilai CCA namun tidak terlalu signifikan (Gambar 6). Sedangkan Gambar 7 menunjukkan peningkatan voltage pada BLA.

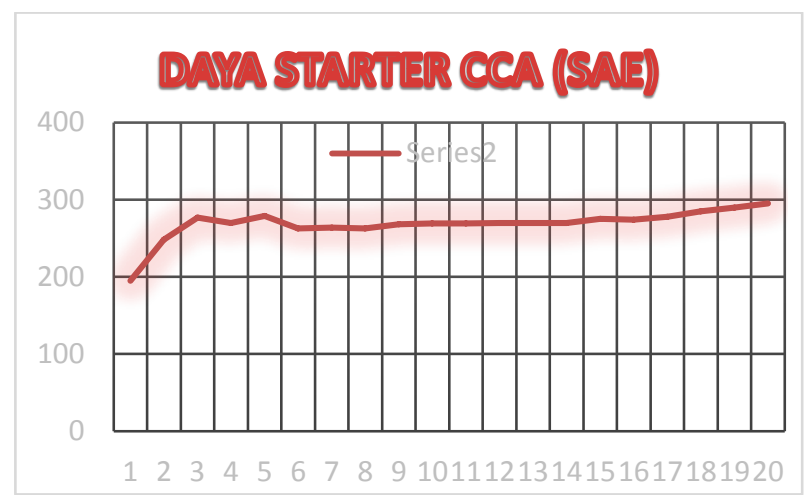

Gambar 6.Siklus charging dan peningkatan daya starter

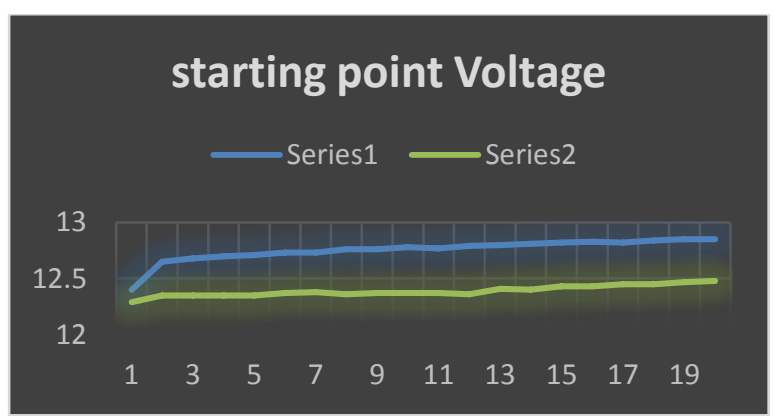

Gambar 7.Peningkatan voltase dalam keadaan setelah charging dan discharging

\section{Pengaruh siklus charging terhadap waktu charging.}

Untuk mencapai voltase $13,5 \mathrm{~V}$ diperlukan waktu charging yang cukup lama pada siklus awal, namun semakin cepat pada siklus-siklus selanjutnya. Hal ini disebabkan besarnya internal resistance pada BLA karena masih tebalnya plak timbal sulfat. Dengan berjalannya siklus charging, timbal sulfat makin berkurang sehingga proses charging semakin cepat. Dengan demikian BLA mendapatkan kembali kapasitas dalam menyimpan muatan listrik. Selain itu itu secara visual cairan
$\mathrm{H} 2 \mathrm{SO}_{4}$ pada BLA terlihat lebih jernih dari yang sebelumnya terlihat agak keruh.

\section{KESIMPULAN DAN SARAN}

\section{Kesimpulan}

Berdasarkan hasil eksperimen di atas, pemberian pulsa tegangan pada BLA akan meningkatkan kapasitas penyimpanan BLA, peningkatan kapasitas ini akan semakin baik pada siklus charging dan discharging. Pada siklus awal proses charging akan membutuhkan waktu lebih panjang karena masih tingginya nilai internal resitance atau tegangan dalam pada baterai, tetapi dengan semakin menurunnya nilai internal resistance maka kapasitas penyimpanan BLA akan lebih baik dan waktu charging akan lebih singkat. Prototipe menghasilkan pulsa tegangan yang dapat menungkatkan kapasitas baterai

\section{Saran}

Penggunaan teknologi charging dengan pulsa tegangan sangat menjanjikan untuk diterapkan pada baterai-baterai berbahan timbal sulfat untuk memperpanjang usia pemakaian BLA, selain itu hal ini akan berakibat baik untuk mengurangi pencemaran lingkungan yang disebabkan oleh sampah-sampah BLA.

\section{DAFTAR PUSTAKA}

[1] L.T. Lam, H. Ozgun, O.V. Lim, J. Power Sources, 53, p. 215, 1995.

[2] P. Ruetschi, J. Power Sources, 127 p. 33-44, 2004.

[3] H. Ikeda, S. Minami, Song JieHou, Y. Onishi, A Kozawa .J. Asian Electric Vehicle, 3, p. 683, 2005.

[4] B. Culpin, A.F. Hollenkamp, D.A,J. Rand,J. Power Sources, 38, p.63-74. 1992.

[5] C.V. D'Alkaine, L.M.M. De Souza, P.R. Impinnisi .J. Power Sources, 158, p. 997, 2006.

[6] http://www.yuasa.com.tw/_english/02 automobile/ 01_list.php?CID=1 (tanggal akses 12 januari 2014)

[7] http://en.wikipedia.org/wiki/Automotive battery (tanggal akses 12 januari 2014) 